\title{
Es ist wieder Zeit für Osler ...
}

\section{Werner Bauer}

Dr. med., Mitglied der Redaktion

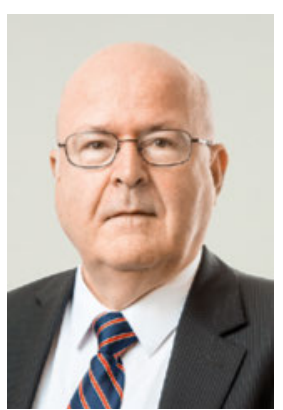

Es ist erheiternd zu erleben, dass es wenig braucht, um ein Prädikat zu bekommen, das einen dann über lange Zeit begleitet und an das man immer wieder erinnert wird. In meinem Fall geht es um den Ruf, ein begeisterter Fan von Sir William Osler zu sein. Das trifft zu, ich bin immer wieder beeindruckt von der Aktualität vieler Gedanken dieses legendären Internisten, der 1849 in Kanada geboren wurde, zu den Gründungsprofessoren der Johns Hopkins Medical School in Baltimore gehörte und 1919 in Oxford starb. Er ist Verfasser des berühmten Lehrbuches «The principles and practice of medicine», einer hohen Schule der Beobachtung am Krankenbett. Zudem sind viele andere Texte und Zitate aus Vorträgen von ihm überliefert*, von denen manche auch beim Blick auf heutige Fragestellungen und Probleme erstaunlich aktuell sind oder zumindest anregende Anstösse für Überlegungen geben.

Da ich immer wieder gefragt werde, ob mein OslerRepertoire erschöpft sei, möchte ich mit einigen Zitaten dokumentieren, dass dem absolut nicht so ist:

"Medicine is a science of uncertainty and an art of probability.»

Ich kenne keine prägnantere und auch nach über hundert Jahren noch zutreffende kurze Definition des Wesens der Medizin.

"The battle against polypharmacy, or the use of a large number of drugs (of the action of which we know little, yet we put them into bodies of the action of which we know less) has not been fought to a finish. One of the first duties of the physician is to educate the masses not to take medicine."

Dieser Aufruf, Medikamente sparsam und nur bei eindeutiger Indikation einzusetzen, ist heute genauso berechtigt wie offenbar schon damals.

"Soap and water and common sense are the best disinfectants."

Sind wir nicht vor kurzem wieder einmal darauf hingewiesen worden, dass das korrekte Händewaschen die wichtigste Massnahme gegen das Übertragen von Keimen in den Institutionen des Gesundheitswesens ist (wäre)?

"In science the credit goes to the man who convinces the world, not to the man to whom the idea first occurs." Diese Erkenntnis hat in den Jahren, seit Osler sie formuliert hat, schon manch ein Forscher schmerzlich bestätigen müssen.
"To combine in due measure the altruistic, the scientific and the business side of our work is not an easy task. In the three great professions, the lawyer has to consider only his head and pocket, the parson the head and the heart, while with us the head, heart and pocket are all engaged."

Osler käme vermutlich ins Staunen, wenn er den Stellenwert der «business side» in der heutigen Arbeitswelt der Ärzte sehen könnte. Es steht zu hoffen, dass «head and heart» auch in Zukunft gegenüber "pocket» eine genügende Balance aufrecht erhalten können.

"The average physician wastes fifty to sixty percent of his time in going from place to place or in the repetition of uninstructive details of practice.»

Die Produktivität und vor allem die Zeit, welche die Ärzte direkt ihren Patienten widmen können, war offensichtlich schon vor über hundert Jahren ein Thema. "A faculty without its troubles is always in a bad way the water should be stirred. Some ferment should be brewing; the young men should always be asking for improvements, to which the old men would object." The search for static security - in the law and elsewhereis misguided. The fact is security can only be achieved through constant change, adapting old ideas that have outlived their usefulness to current facts.»

Auch dieses Plädoyer gegen statisches Verharren und für die notwendige Weiterentwicklung an den Fakultäten und überhaupt ist zeitlos und müsste auch heute hie und da gehalten werden.

"The practitioner needs culture as well as learning. Start at once a bedside library and spend the last half hour of the day with the saints of humanity."

Ärzte brauchen medizinische Kenntnisse und Fertigkeiten, aber zur Arztpersönlichkeit gehören auch eine vertiefte allgemeine Bildung und entsprechende breite Interessen.

Die letzten zwei Zitate - Osler soll das letzte Wort haben - sprechen für sich und bedürfen keines Kommentars:

"The philosophies of one age have become the absurdities of the next, and the foolishness of yesterday has become the wisdom of tomorrow.»

"I desire no other epitaph than the statement that I taught medical students in the wards, as I regard this as by far the most useful and important work I have been called to do." 